\title{
Trends of European Research and Development in District Heating Technologies
}

\author{
M. A. Sayegh ${ }^{1}$, J. Danielewicz ${ }^{1}$, T. Nannou ${ }^{2}$, M. Miniewicz ${ }^{1}$, P. Jadwiszczak ${ }^{1}$, K. Piekarska $^{1}$, \\ H. Jouhara ${ }^{2^{*}}$
}

\footnotetext{
${ }^{1}$ Faculty of Environmental Engineering, Wrocław University of Technology, Wrocław; Poland

${ }^{2}$ Institute of Energy Futures, RCUK Centre for Sustainable Energy Use in Food Chains (CSEF), Institute of Energy Futures, Brunel University, Uxbridge, UK; Tel. +44 1895 267805, email: hussam.jouhara@brunel.ac.uk
}

Submitted to:

Renewable and Sustainable Energy Reviews 


\section{ABSTRACT}

There is a considerable diversity of district heating (DH) technologies, components and interaction in EU countries. The trends and developments of $\mathrm{DH}$ are investigated in this paper. Research of four areas related to DH systems and their interaction with: fossil fuels, renewable energy (RE) sources, energy efficiency of the systems and the impact on the environment and the human health are described in the following content. The key conclusion obtained from this review is that the DH development requires more flexible energy systems with building automations, more significant contribution of RE sources, more dynamic prosumers' participation, and integration with mix fuel energy systems, as part of smart energy sustainable systems in smart cities. These are the main issues that Europe has to address in order to establish sustainable DH systems across its countries.

Keywords: district heating, energy technologies, renewable energy, sustainability in district heating

\section{INTRODUCTION}

District energy systems (DES) supply the consumers with electrical and thermal energy, in the form of electricity and heating or cooling. DES are a proven energy solution that has been deployed for many years in a growing number of cities worldwide. DES implementation in city's networks offer significant benefits, including an affordable energy provision system, an increased share of renewable energy (RE) sources in the energy mix of the country, the city's autonomy from energy and fossil fuels imports and its control over its energy supply, the economic development of the local community and local air quality improvements by $\mathrm{CO}_{2}$ emission reductions. Especially the combination of DES and combined heat and power (CHP) systems enhance the economic and environmental benefits of the technology, since CHP systems provide the ability of recycling waste heat. These systems can be integrated into large scale for district heating (DH) and cooling applications $[1,2]$. DH systems are considered to be valuable assets of the energy supply networks, which enable the efficient resource utilization [3].

Currently, DH networks are well-established in many countries and possess an important part of DES. The operational principle of the system is to produce heat centrally and later distribute it to consumers through pipes buried in the ground, in order to cover their heating and domestic hot water (DHW) demands.

DH networks come in a variety of scheme sizes, able to cover the needs of a small group of buildings in the same neighborhood or city-wide schemes comprising thousands of connected buildings. DH systems are characterized by a diversity of technologies that seek to develop synergies between the power, the heat production, the supply heat, the cooling and the DHW applications of the users. The flexibility of DES allows their integration with thermal renewable technologies, such as biomass, solar thermal, heat pumps, deep geothermal, etc., a fact that can significant reduce the overall carbon gases emissions.

One of the most promising technologies towards the development of sustainable DES is CHP and combined cool, heat and power (CCHP) systems. CHP systems are usually located near commercial or residential buildings, where the waste heat produced by the turbine of the system is readily recovered and used to heat near located buildings [4]. This is typically done by the means of a DH loop, in which hot water, steam, or another medium is used to transport the heat to buildings' network [5]. In CCHP systems besides a DH loop, a district cooling (DC) loop can be used to provide cooling to the buildings. Similarly, DC systems use centrally located chilling equipment to generate cooling in the form of chilled water or another medium, which is later distributed to nearby buildings [6].

The potentials of these sustainable DES can be realized if one considers the fact that the largest amount of energy in the Europe is consumed for space heating and hot water preparation for buildings, reaching the $43 \%$ of the total Europe's final energy consumption [7]. Sustainable DES can efficiently cover these consumers' needs. However, the energy demand profile of the consumers must be taken 
into account, as the demand characteristics are constantly changing. In order to regulate the relationship between the energy demands, the energy production and the energy distribution, advanced and complex control, forecast and energy management systems are required. A variety of software and models for DH supply systems are used to overcome the different heat demand purposes, always considering the supply reliability of the system [8].

\section{DH Overview}

DH is a term established in the United States in the late $19^{\text {th }}$ century, and came in Europe in the beginning of the $20^{\text {th }}$ century. The first generation of DH systems was developed in 1880 's and consisted of radiators, which were making use of the steam condensation to provide heat. In 1930's the second generation of systems was presented in the markets, in which hot water (higher than $100^{\circ} \mathrm{C}$ ) under pressure was used in the radiators, while the first CHP systems were introduced in the DH networks. The third generation of DH systems, in 1970's, was using pressurized water of low temperatures (below $100^{\circ} \mathrm{C}$ ) and instead of petrol oil various local fuels like coal, biomass or waste were used. Currently, RE sources such as solar and geothermal systems, are progressively incorporated into DH networks [9-13]. Nowadays, the trend is towards lower distribution temperatures of water between $30-70^{\circ} \mathrm{C}[14]$. The lower the $\mathrm{DH}$ return temperature is, the greater the energy efficiency of the plant is, leading to a decrease of fuel consumption and carbon footprint.

Currently, in Europe 4,174 DH systems exist, while the energy market share of DH systems corresponds to $10 \%$ of the heating market in Europe [7]. However, many of them around the world require small modifications of modernization (i.e., retrofitting) to bring them to a reliable standard. $\mathrm{DH}$ enables the use of a variety of heat sources that are often wasted, as well as the renewable heat $[4,15]$. Many researchers have focused their field of studies to investigate methods and advantages of reusing the waste energy, RE utilization, modelling of DH systems and components [8,16-21]. DH systems can significantly contribute achieving the goals of EU's energy policy in perspective of 2050 [22].

The main advantages of DH systems are that they can be incorporated into existing heating facilities with reasonable cost, using a mixture of RE sources and conventional fuels. The combination of conventional and RE technologies creates hybrid systems, which are capable to achieve better system's performance. Energy savings in buildings is a key point towards a more sustainable energy future, with the most feasible action first to renovate buildings that are planned to be connected into DH networks. Therefore, energy planning and area mapping is necessary, in order to define zones where building renovation and DH development is promoted. The energy savings obtained from $\mathrm{DH}$ network extensions seem an attractive solution from an energy and environmental point of view. However, the economic viability of DH systems still needs to be evaluated. Actually, the current key challenge is to find an optimized economic and energy solution combining both the future development of DH systems and the energy savings [23-27].

The DH technologies vary in many ways in the EU countries, depending on each country's energy policy, energy security, economic development, access to new and innovative technologies, reliance of own fuel resources, regulations, climatic and local conditions. Therefore, the development of DH systems differs in terms of energy efficiency, $\mathrm{CO}_{2}$ emissions and use of RE sources in each country. However, the ultimate goal is to create a common EU energy legislation regarding DH networks and technologies.

A general scheme of DH is presented in Figure 1 and describes the operation and the connections of a $\mathrm{DH}$ network. The main parts of a DH system are a heat source, a heat transport network and several substations to supply the energy to the consumers. In that way, the end users have only a simple on site unit consisted of heat exchangers, pumps and valves. Some of the benefits of DH installations are that the onsite units of the consumers do not require annual maintenance comparing to the combustion chambers and that the consumers are not facing the risks associated with onsite fuel storage and delivery [28]. 


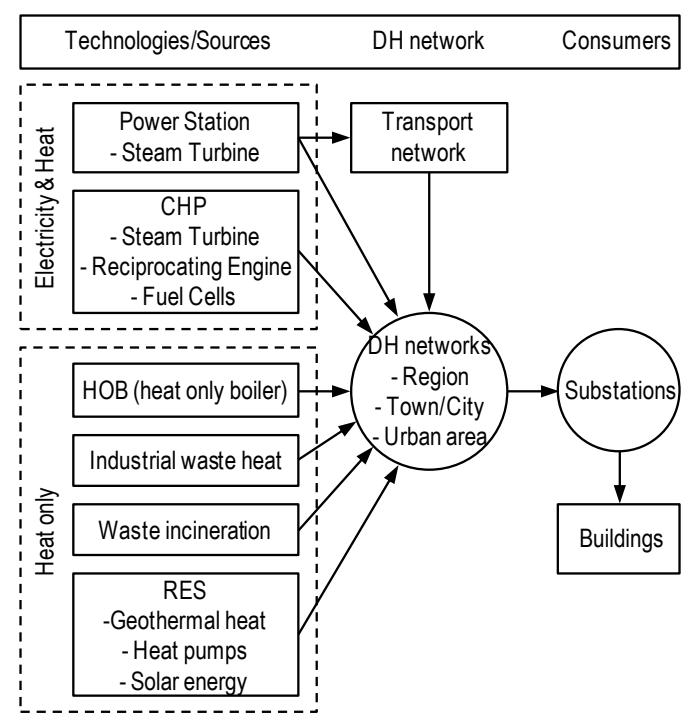

Figure 1: DH system components and technologies

DH systems consist of one or more central sources and a network of insulated pipe to provide hot water to end users. The energy technologies used for DH applications can be categorized into two groups: CHP systems and heat only systems as it shown in Figure 1. CHP systems use the rejected or waste heat from the power generating units to produce hot water. CHP systems have been widely used for several decades now. The most common technologies of these systems are steam turbines with coal, turbines and gas engines with innovative fuel cell technologies. The term 'heat only systems' refers to steam generating systems or hot water boilers, with the use of conventional or renewable fuels (biomass), industrial waste heat, municipal waste incineration plants and RE sources, such as geothermal heating plants, heat pumps and solar energy [7,29].

The basic energy sources used in DH systems are fossil fuels such as coal, gas and fuel oil, as well as RE sources. Figure 2 represents the share of fuels used in CHP systems in Europe, for the year 2009. It is obvious from figure 2 that the two dominant fuel categories are coal (34.8\%) and gas (39.4\%). However, this fuel distribution may differ for each EU country.

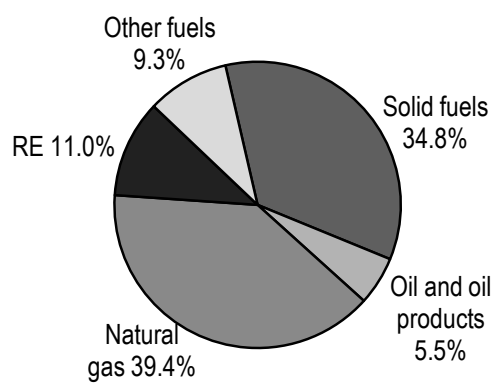

Figure 2: Share of fuels in CHP systems in EU [5]

The main advantage of DH systems against the separated heating methods is the wide variety of energy sources that they can use, such as biomass (straw, wood waste), municipal waste, RE resources (geothermal, solar) and industrial waste heat.

DH systems can use different energy sources in a common cycle, creating hybrid systems, which gives a significant technological advantage and the potentials of further development. These hybrid systems combine conventional methods of energy production from fossil fuels, with the use of alternative and RE technologies, like heat pumps, solar collectors or gasification of fuels (coal, biomass). As a result, hybrid systems manage to achieve higher energy efficiency and greater fuel savings, while minimizing their environmental impact. The transition from conventional energy technologies to combined DH systems is already noticeable in Europe. 


\section{MAIN PRINCIPLES OF ANALYSIS}

The current state of DH in Europe and its development are characterised on the basis of technical information, scientific diagnosis and statistical analysis. In this paper several types of DH systems, heat sources, potentials end users, DH management tools and health effects are presented. A sustainable DH system aims to reduce the consumption of conventional fossil fuels, to increase the share of RE sources, to improve the energy efficiency of the system and to reduce the impact of DH on the environment and the human health [30-33].

Currently, energy sustainability is an important and common goal for all EU countries. However, the implementation of fully sustainable DH system which will satisfy all the above aims meets various obstacles, due to the limited availability of local energy sources and fuels, energy policies, innovation, economic conditions, environment and health protection, etc. The only feasible solution to overcome these problems is the development of a common EU energy legislation regarding DH networks and their technologies [25,34-38].

\section{ENERGY TECHNOLOGIES IN DH}

According to Figure $1 \mathrm{DH}$ technologies are divided into CHP and heating-only technologies. These two categories are analyzed in the following text.

\subsection{Combined Heat and Power Systems}

One of the most desired characteristics of CHP plants is their electricity production. The generation of electricity is a result of the conversion of fossil fuel's chemical energy to thermal and mechanical energy, which powers the generator of the system. Electricity production by conventional-separated methods is characterized by low efficiency rates, around $\eta_{e l}=0.15-0.4$, with the average efficiency of conventional plants in the EU being around 0.38. CHP systems achieve higher energy efficiency rates and less fuel consumption and carbon footprint, compared to the separated processes of heat and power generation. Moreover, more advanced CHP technologies allow the recovery of the system's waste heat to provide cooling, along with heating and power. These systems are called Combined Cooling, Heating and Power (CCHP) plants.

Currently, the most widespread technologies of power generation in CHP systems are steam turbines, gas turbines, combined gas-steam turbines (GTCC-gas turbine combined cycle), gas engines with spark ignition and diesel engines. The thermal energy produced during the fuel combustion is later used for heating the water of DH systems or to produce high-pressure steam (HP), for further system's operations. In that way, the waste heat of the system is continuously used in the generation process, improving the electrical efficiency of the system [39-42] .

The electrical power produced by individual units in power plants ranges from 40 to $1000 \mathrm{MW}_{\mathrm{el}}$. The typical components of power generation plants are steam boilers, steam turbines, condensers, circulating pumps and a closed power cycle of working fluid, which is usually water. The power efficiency of these generation units depends on steam's and water's thermodynamic cycle parameters.

One of the greatest concerns of conventional power plants is theirs pollutants emissions, particularly of $\mathrm{CO}_{2}$, caused by coal combustion. It is estimated that the global rate of $\mathrm{CO}_{2}$ emissions from coal power plants with efficiency of $\eta_{e l}=0.30$ is approximately $1,115 \mathrm{gCO}_{2} / \mathrm{kWh}$ a value that exceeds the limit of $454 \mathrm{gCO}_{2} / \mathrm{kWh}$, set by the US Environmental Protection Agency (EPA) by 2.5 times [21]. It is possible to reduce the $\mathrm{CO}_{2}$ emissions, by implementing coal/biomass co-burned technologies, combined coalburned boilers with biomass boilers or new constructed biomass boilers [43].

One of the benefits of CHP units is that the user can control the ratio between the thermal energy supplied to the DH system and the generated electricity from the unit. The thermal and the electrical energy produced by the CHP plant is characterized by an inversely proportional relationship; the 
production of higher amount of heat corresponds to less generated power. In the literature this behavior is compared to the operation of virtual heat pumps. The virtual heat pump coefficient of performance (COP) is described as proportion of the heat supplied to the DH system and the unproduced electricity [44]. For a traditional heat pump the COP is around 3 to 4, while for a virtual heat pump the COP ranges between 6 and 10. Power plant units are more efficient when are operated in baseload mode. Peak water boilers can be integrated to produce extra heat load, in order to cover the heat demands.

The last twenty years, the driving technology in the field of electricity generation is gas turbines or engines. The developed gas technologies find application in large scale CHP plants and in small/micro scale systems.

\section{Gas turbines (GT)}

Gas turbines consist of an electricity generator, a gas turbine, several compressors installed on the same shaft and a combustion chamber. The electrical efficiency of a GT usually ranges between $\eta_{e l}=0.35-0.42[45,46]$. The typical range of electrical generation by GT rates between 1 to $40 \mathrm{MW}_{\mathrm{el}}$, and between 1 to $250 \mathrm{MW}_{\text {el }}$ for industrial turbines. The ratio of power to heat, produced by GT, is in the range of $0.5-2$, which is considered to be one of the highest ratios compared to other systems. The high temperature of the exhaust gases of the GT $\left(>450{ }^{\circ} \mathrm{C}\right)$ allows the production of hot water and high or low pressure steam. However, the cost of electricity production by GT is higher than coal-burning technologies, mainly due to the price of gas. For that reason, GT are used in cases of peak demand electricity.

\section{Gas-steam turbines}

Gas-steam turbines combined cycle (GTCC) have higher electrical efficiency comparing to GT. GTCC systems have the ability to further use their waste heat back to the process of the electricity generation. GTCC consist of a heat recovery steam generator (HRSG), a steam turbine and a condenser. The heat supplied in the DH network is produced by the condenser of the steam turbine, the waste heat exchanger and the exhaust gases boiler. The existing GTCC systems can achieve up to $\eta_{e l}=0.59$ electrical efficiency [45]. GTCC power plants are suitable for covering large proportion of DH demands.

\section{Gas engines}

Reciprocating gas engines [46] are widely used in CHP units, especially for small DH applications and individual buildings. These systems can provide $5 \mathrm{~kW}_{\mathrm{el}}$ to $8 \mathrm{MW}_{\mathrm{el}}$ of electrical power. Their electrical efficiency is in the range of $\eta_{e l}=0.2-0.4$, while their power to heat ratio is between 0.5 and 1 . Furthermore, this type of systems considers being very competitive in terms of volumetric investment cost, compared to other thermal and power solutions. The heat recovery system uses the temperature of the exhaust gases, which is between 380 and $550^{\circ} \mathrm{C}$, and the engine cooling temperature, which is below $90^{\circ} \mathrm{C}$. Hence, they are most often used for low-temperature $\mathrm{DH}$ applications. Spark-ignition engines or diesel engines can also be used, but they require constant cooling of their engines. Usually, they are working in the base heat load and the peak heat demand is covered by water boilers. In some cases heat storage are also installed in order to maximize the production of electricity in cases of which the base load production is not sufficient.

\section{Fuel cells}

Fuel cells enable the production of electricity and heat by the direct conversion of chemical energy of the fuel. They are characterized by higher efficiency rates compared to the traditional energy technologies formerly described [47]. The achieved efficiency of electricity depends on the type of fuel cell used and usually ranges between 30 to $60 \%$. The use of fuel cells in DH systems increases the 
efficiency of the fuel cells up to $90 \%$. The operating temperature depends on the catalyst design and the type of electrolyte used and ranges from 50 to $200^{\circ} \mathrm{C}$ and from 600 to $1000^{\circ} \mathrm{C}$. The generated electric power by current fuel cells ranges from 3 to $1000 \mathrm{~kW}$ and can reach up to $10,000 \mathrm{~kW}$. Fuel cell technology is mainly used in applications of small and medium scale power systems $[46,48-50]$.

The power to heat ratio of fuel cells ranges from 0.5 to 1.4 . The basic fuel used in fuel cell technology is hydrogen, but it is possible to convert other hydrocarbon fuels to hydrogen, by the process of reforming. In combination with other technologies (gas, steam turbines) fuel cells can achieve electrical efficiency rates up to $60 \%$. However, until now large scale fuel cell DH systems do not exist, due to the high costs of the fuel cell production.

\subsection{Heat-only Systems}

\section{Boilers}

Heat-only boilers (HOB) are probably the oldest system of DH networks. They can be stand alone, as a heat source in DH applications or they can be part of a greater heat system of power plants. The boilers use conventional solid fuels, like coal, oil, natural gas, etc. However, one of the recent developments in the field is the use of boilers burning two types of fuels; conventional fuels and biomass. Biomass is used as a fuel in form of straw, wood chips, forest waste, biofuels and biogas. The thermal efficiency of a system like this ranges between $\eta_{t h}=0.85-0.97$ [45]. In addition, higher efficiency is achievable by gas-fired boilers, using exhaust condensation techniques. Solid fuel boilers with grate furnaces show the lowest thermal efficiency. Water boilers are characterized by long-term employment without a significant reduction of efficiency, as long as regular maintenance is provided. $\mathrm{HOB}$ can be used in small and medium-sized heating systems $\left(<100 \mathrm{MW}_{\text {th }}\right)$, in which the use of CHP units is not profitable.

\section{Heat pumps}

DH multi-stage heat pumps (compressor and absorber) and hybrid systems (absorption-compression) are often used in DH systems. The COP of heat pumps ranges between 2.5 to 5.5, depending on the cooling and temperature levels of the lower source, the properties of the working fluid $\left(\mathrm{CO}_{2}, \mathrm{NH}_{3}\right)$ and the temperature range of the upper source [45]. The COP of absorption heat pumps ranges between 1.7 and 2.3 for two-stage systems. Absorption heat pumps require high temperature steam, gases or water as a lower heat source $[51,52]$.

\section{Geothermal heating plants}

Geothermal DH plants are another example of RE use, where the thermal energy stored in the ground is used to supply the DH network. Geothermal heating plants are installed in depth of 800 to $3000 \mathrm{~m}$ underground where the temperatures ranges between 30 to $90^{\circ} \mathrm{C}$ with low salt levels. Typical geothermal DH systems consist of heat exchangers (geothermal water/network water), a compression or absorption heat pump (for additional cooling of geothermal water) and a peak water boiler. Gas burners or hot-water boilers fired by gases or biomass are used for driving the absorption heat pumps $[9,11,13]$.

\section{RE utilization}

Some of the RE sources used in DH systems are solar energy, geothermal energy, biogas and biomass $[53,54]$. The ultimate goal of EU countries is their independency from fossil fuels. Existing DH systems can be integrated with RE technologies, with small modifications and reasonable cost. The modifications require low temperatures and the incorporation of a heat losses network [55]. Out of the approximately 5,000 DH systems in Europe, 250 are using geothermal DH technology, while it is estimated that over $25 \%$ of the EU population live in areas suitable for geothermal DH applications [56]. 
However, DH systems using only RE sources are not very common. They usually combine conventional energy sources with other kinds of RE sources and thermal or energy storage. Energy storage is an essential part of DH systems due to the fluctuating energy supply from RE resources such as solar (thermal, photovoltaic, photovoltaic/thermal) or wind energy. RE can be integrated to the DH systems by central or onsite heat sources. Local RE installations reduce the heat consumption of the DH system, without any physical connection to the network. Figure 3 represents the possible connections of RE sources in DH systems. In central mode (Figure 3A) the RE sources deliver heat to the main heat source with large seasonal heat stores. In distributed mode (Figure 3B) the RE sources are placed at suitable locations and connected directly to the DH system. These plants usually utilize the DH system as storage.

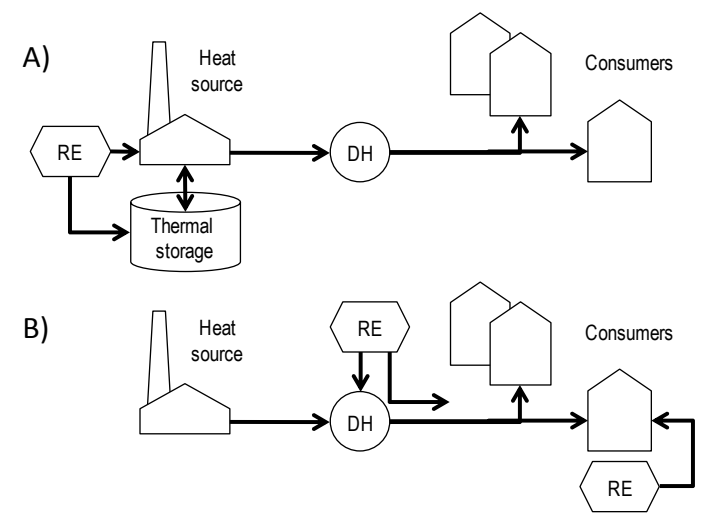

Figure 3: Integration of RE to $\mathrm{DH}$

There are thousands of DH systems in Europe, but a small percentage of them uses RE sources as a heating/cooling system [7]. The legislation of using RE sources in DH installations varies both at national and regional levels. Most of the heat requirements comply with the EU Energy Efficiency Directive 2012/27/EU [57]. There are different barriers for large scale RE resources for DH systems, like the price of the land or restricted application on historic or protected areas, financial incentives for $\mathrm{RE}$ etc. However, all $\mathrm{DH}$ systems in Europe are operated at temperatures over $70^{\circ} \mathrm{C}$. The implementation of RE sources in the DH may reduce the total annual conventional energy demand of buildings. However, the strict legislation and the lack of practice experience and knowledge of the RE integration in DH systems are the main reasons why there are few applications of those large scale RE integrated in DH systems. The EU tries to overcome these barriers by updating the directives and providing local and regional support policies and funding.

\section{MONO, MULTI-FUEL AND SMART DH}

The first DH systems were based only on single fuel heat sources (mono-fuel). In the extensive urban systems two or more sources are combined to cover the heat demands, most importantly as back up in case of one of the sources fails. These multi-fuel DH sources operate according to the energy demands and the sources' availability. The integration of energy sources with thermal storage increase the utilization of RE and DH efficiency. The more significant heat sources of DH systems are recycled heat from fossil fuels, from CHP and from industries, followed by direct use of fossil fuels, or recycled heat from renewable CHP (waste and biomass) and at last by direct use of RE sources, like geothermal, biomass and waste. [58,59] 


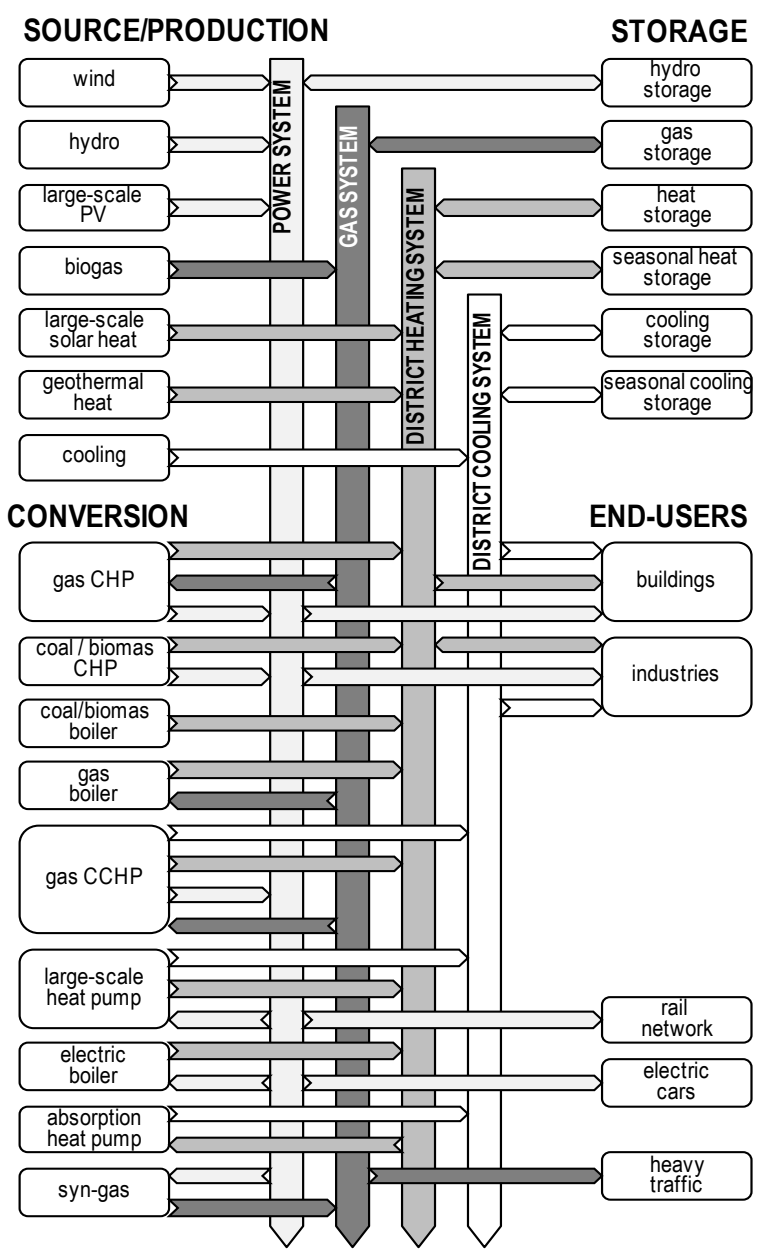

Figure 4: Multi-fuel smart energy system

The DH flexibility and efficiency are improved by joining the DH networks with city energy grids. The integrated multi-energy systems (MES) use energy obtained from multiple energy sources and produces electricity, heat and cooling as a switched network. This integration increases the technical, economic and environmental performance of the network. MES is the main part of smart energy systems (SES) or smart cities, as they are called. SES enables the storage and transfer of the energy between the networks (Figure 4). Until now fully SES or smart cities do not exist; only few projects, which operate as a switched energy network $[30,33,35,60]$.

\section{DH MANAGEMENT}

The management term in DH systems refers to the technical operations, the maintenance, the energy and economic management, the continuous development and the modernization of the system.

\section{Control and forecast}

An optimal DH operation means to meet the consumers, environmental, economic and technical requirements. An accurate forecast of heat consumption offers the possibility of increasing the thermal efficiency and minimizing the fuel consumption and emissions. Initial designs of DH systems provided heat to the consumers, based on the ambient temperature (Figure 5A). This has led to a discrepancy between the energy demand and the supplied heat. Attempts were made to eliminate this disadvantage, by taking into account additional metrological factors, weather data reports and demand forecasts. Good results in DH management were achieved by using weather data control, modelling of buildings' consumption and modelling of DH systems (Figure 5B). In the literature different models are described: simple, complex, statistical, simulations, learning, adaptive and other. Currently, the most successfully model-based method uses both hierarchical and multi-agent control systems. 
Improved automatics and metering methods lead to better management of the heat source, the network's distribution and the heat consumption, simultaneously including DH and DC, heat/cool accumulation in network or in buildings, integration of prosumers, etc. Many existing DH systems operate on model-based methods. Smart DH networks use multi-variant simulations, online monitoring, supervisory control and data acquisition (SCADA), emulators, thermal and hydraulic models, geographic information system (GIS) and other decision support tools. The most favourable operation scenario of DH networks is to automatically determine and implement the necessary control functions (Figure 5C).
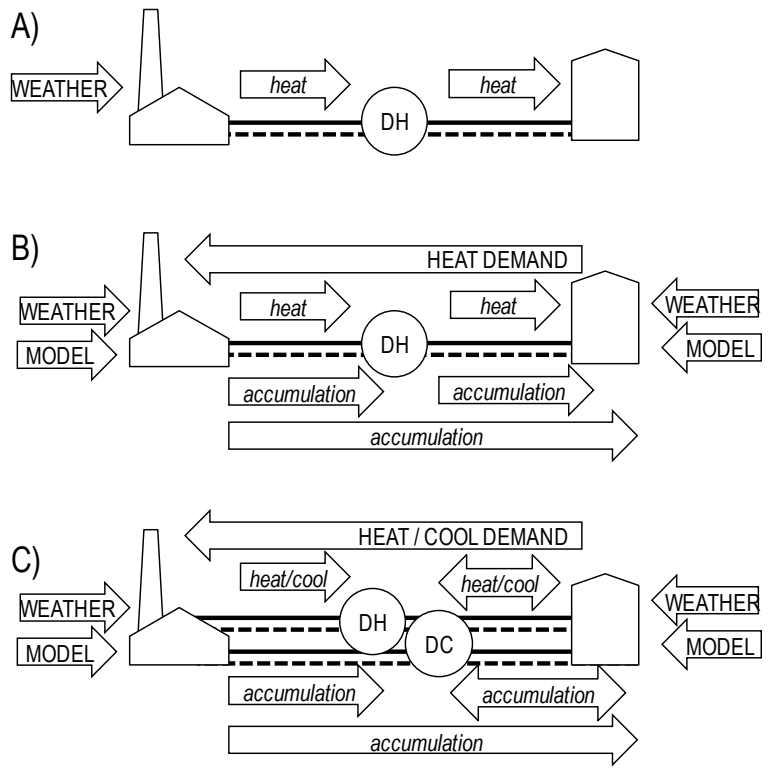

Figure 5: DH control and forecast

\section{Reliability}

The reliability of a DH network is an important issue, in addition to the adjustment of energy supply and demand. In the first DH systems, only the occurring system's failures could be detected. Then, periodic inspections and monitoring allowed early detection of threats. Currently, prevention systems, automated detection, localization of failures and eliminating their effects, via SCADA monitoring, thermal mapping, GIS and other tools are used to ensure the networks reliability [8].

\section{Expansion and development}

Today's challenge is to find expansion potentials of existing DH systems. In that direction GIS, heat atlases, databases, statistics of energy producers, life cycle assessments (LCA), powerful simulation tools including technical, economic, energy efficiency and environmental aspects are used [61].

DH should keep pace with developments in technology, regulations and heat production methods. Until now, the developments of DH systems relied on network expansions and capacity improvements of the sources. The new challenges that the field of $\mathrm{DH}$ is facing are the increasing consumers' heat demands, the fluctuations of heat production and difficulties to efficiently cover the needs of consumers in urban centres and remote areas. However, networks are not easily expanding due to the pumping cost and heat losses. Usually, the development of new local DH networks and the division of existing networks (decentralization) are more profitable than the expansion of existing network. The constant changes require periodic verification of the strategy, forecasting and management methods of $\mathrm{DH}$. 


\section{CONSUMERS IN DH}

The building sector consumes approximately $40 \%$ of the total produced energy in the EU [62]. Power production in the building sector is associated with the $36 \%$ of the total $\mathrm{EU} \mathrm{CO}_{2}$ emissions [62]. In addition, the thermal energy production corresponds to approximately $80 \%$ of the total energy consumption [62]. The high energy consumption of the building sector is mainly caused by the low energy efficiency of buildings. Nearly $40 \%$ of the buildings in EU were built before 1960's and only $18 \%$ of them fulfil the strict energy performance requirements, while their energy consumption is 5 to 10 times less than prior constructed buildings [63]. Currently, due to the Energy Performance Building Directive (EPBD) 2002/91/EC requirements the annual energy consumption of buildings is around 34 to $125 \mathrm{kWh} / \mathrm{m}^{2}$ [61].The potential of energy savings in the building sector is enormous. It is estimated that $75 \%$ of the existing buildings in EU are inefficient. The energy sources used for heating in the EU buildings vary considerably, depending on the EU region as it can be seen in Table 1.

Table 1: Heating sources in residential buildings (Europe
\begin{tabular}{|c|c|c|c|}
\hline \multirow{3}{*}{ Heat source / fuel } & \multicolumn{3}{|c|}{ EU region } \\
\cline { 2 - 4 } & South & $\begin{array}{c}\text { Central } \\
\& \\
\text { East }\end{array}$ & $\begin{array}{c}\text { North } \\
\& \\
\text { West }\end{array}$ \\
\hline Biomass & $27 \%$ & $20 \%$ & $21 \%$ \\
\hline Electricity & $18 \%$ & $1 \%$ & $13 \%$ \\
\hline Oil & $32 \%$ & $3 \%$ & $20 \%$ \\
\hline Gas & $23 \%$ & $7 \%$ & $39 \%$ \\
\hline DH & 0 & $29 \%$ & $6 \%$ \\
\hline Coal & 0 & $41 \%$ & $1 \%$ \\
\hline
\end{tabular}

Central and eastern EU regions are characterized by a high share of DH applications for residential buildings, mainly in large urban areas with large reserves of local coal for heating, compared to other EU regions where the dominant energy source is gas and fuel oil. Figure 6 presents the percentage of contribution of each EU country in supplying the DH system, which varies from 1 to $92 \%$.

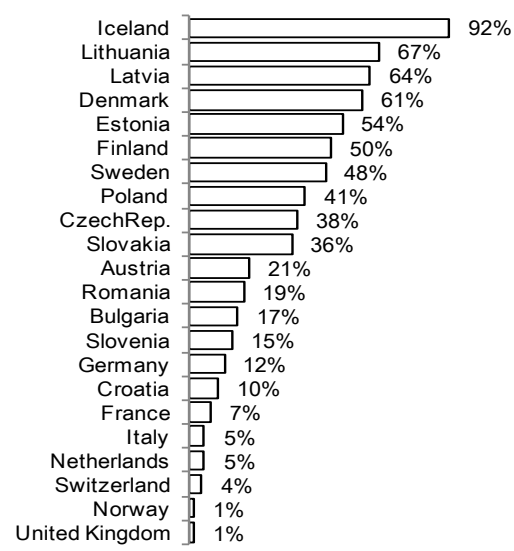

Figure 6: EU countries participation to DH systems [65]

Improvements to buildings' energy efficiency, particularly in central and eastern EU countries, and further development of energy-efficient heating systems can save significant amounts of fossil fuel and reduce $\mathrm{CO}_{2}$ emissions.

\section{POLLUTANTS EMISSION}

The energy sector is considered to be the largest source of $\mathrm{CO}_{2}$ and greenhouse gases (GHG) emissions worldwide. Due to the changes of the legislation the last 25 years, $\mathrm{CO}_{2}$ emission in most EU countries have been visibly reduced [65]. But there are also countries where the emission rates have increased, and these countries can be seen in Figure 7. The factors that helped to significantly reduce 
the $\mathrm{CO}_{2}$ emissions are the development of filters for gases after treatment, the improvement of the energy efficiency in heat production systems and the increased use of RE sources [66].

Air pollutants are emitted directly into the atmosphere or reformed secondarily in the atmosphere [67]. The concentration, the chemical composition, the quantity and the type of pollutants vary, depending on the sources of emissions, the air masses movement and the weather and topographical conditions. Coal combustion is one of the most polluting energy conversion methods. Short-term exposure causes respiratory diseases, heart arrhythmia and allergic reactions. Prolonged exposure increases lung cancer risks, respiratory and cardiovascular diseases, arteriosclerosis and neurobehavioral changes. Air pollution is undervalued in the health system [22,68,69]. The turning point in air protection actions was the black smoke in London (1952). Similar episodes of black smoke occurred in Western Europe (1989 and 1993). The high concentrations of $\mathrm{CO}_{2}$ and fine dust particles was the result of air pollution movement from the East to west Europe [67]. The fuel combustion in DH applications takes place under controlled, technologically and ecologically conditions. Compare to local heat sources (low emission) DH systems produce fewer emissions, even in case of burning coal as heat source.

\section{$\begin{array}{ll}\text { A) } \mathrm{CO}_{2} \text { emission in } 2012 & \text { B) } \% \text { change 1990-2012 }\end{array}$}

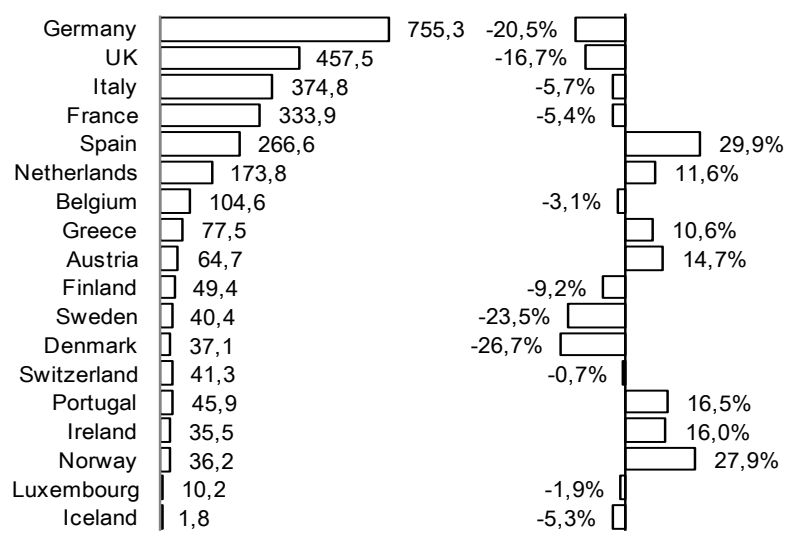

Figure 7: $\mathrm{EU} \mathrm{CO}_{2}$ emissions in $\mathrm{MtCO}_{2}$ of fuel combustion and percentage of change in $\mathrm{CO}_{2}$ emissions [70]

\section{CURRENT AND FUTURE TRENDS}

The DH systems exist in different schemes and stages across Europe. Mainly, the northern, central and eastern EU countries have the highest production of DH, with Poland and Germany leading the market with the greatest amount of energy supply from DH networks. In Scandinavian countries DH systems cover up to $90 \%$ of the residential heat demands.

Two scenarios are foreseen for the future of DH systems in Europe. First of all, the improvement of existing systems and the development of the next generation of DH systems, with higher efficiency and lower costs, as well as the expansion of the heat sources' range with conventional and RE sources. The second scenario is the refurbishment of old, less efficient systems by new technologies towards hybrid systems with better performance. Finally, the expansion of existing networks in all scenarios is essential in the future of DH systems. The EU legislation and the regulations regarding DH systems are changing in order to support the DH networks development across Europe for sharing the produced energy [58]. The future EU trend is towards sustainable DH development which will be feasible by reducing the consumption of conventional fuels, by increasing share of RE, by improving energy efficiency and by reducing the impact of the systems on the environment and the human health.

\section{CONCLUSIONS}

Existing technologies of DH systems in EU countries are characterized by a great diversity of applied technologies and the use of RE sources. The degree of modifications that should be made in the 
existing DH systems in EU, in respect to the EU goals of 2020 and 2050, differs for each country but are directed towards sustainable development in all EU countries. It is believed that DH systems are capable of achieving all sustainable goals at a lower cost compared to every other technology by $15 \%$ [22].

It should be noted that the DH size and location does not only depend on the climatic conditions. Its utilisation is highly dependent on national energy policies that play significant role in its the adoption on national levels.

All technologies in DH systems are constantly upgrading and improving. The aim is to improve the efficiency of heat generation and transmission, increase RE uses and to reduce the impact on environment and human health. Contemporary technologies enable sustainable development of small and medium scale DH by using large scale energy sources technologies i.e. CHP, GT, fuel cells, heat pumps, RE etc. It is preferable to use contemporary technologies with energy storage. The DH development requires more flexible energy systems with building automation, RE and increasing the role of prosumers participation, integration with mix fuel energy systems as part of smart energy sustainable systems in smart cities.

\section{ACKNOWLEDGMENTS}

This research was conducted in collaboration between Wrocław University of Technology (Poland) and Brunel University London (UK). The support for the Polish team was by the Ministry of Science and Higher Education under grant No 50532.

\section{REFERENCES}

[1] United Nations Environment Programme. District Energy in Cities: Unlocking the Potential of Energy Efficiency and Renewable Energy. 2015.

[2] Rezaie B, Rosen MA. District heating and cooling: Review of technology and potential enhancements. Appl Energy 2012;93:2-10. doi:10.1016/j.apenergy.2011.04.020.

[3] Johansson P. Buildings and district heating - contributions to development and assessments of efficient technology. Lund University, 2011.

[4] Thornton A, Monroy CR. Distributed power generation in the United States. Renew Sustain Energy Rev 2011;15:4809-17. doi:10.1016/j.rser.2011.07.070.

[5] Persson U, Werner S. District heating in sequential energy supply. Appl Energy 2012;95:12331. doi:10.1016/j.apenergy.2012.02.021.

[6] Chan A, Chow T, Fong S, Lin J. Performance evaluation of district cooling plant with ice storage. Energy 2006;31:2750-62. doi:10.1016/j.energy.2005.11.022.

[7] Persson U, Werner S. Heat distribution and the future competitiveness of district heating. Appl Energy 2011;88:568-76. doi:10.1016/j.apenergy.2010.09.020.

[8] Nielsen S, Möller B. GIS based analysis of future district heating potential in Denmark. Energy 2013;57:458-68. doi:10.1016/j.energy.2013.05.041.

[9] Bloomquist RG. Geothermal space heating. Geothermics 2003;32:513-26. doi:10.1016/j.geothermics.2003.06.001.

[10] Faninger G. Combined solar-biomass district heating in Austria. Sol Energy 2000;69:425-35. doi:10.1016/S0038-092X(00)00117-1.

[11] Hepbasli A, Canakci C. Geothermal district heating applications in Turkey: a case study of Izmir-Balcova. Energy Convers Manag 2003;44:1285-301. doi:10.1016/S01968904(02)00121-8.

[12] Lottner V, Schulz M., Hahne E. Solar-Assisted District Heating Plants: Status of the German Programme Solarthermie-2000. Sol Energy 2000;69:449-59. doi:10.1016/S0038092X(00)00125-0.

[13] Ozgener L, Hepbasli A, Dincer I. Energy and exergy analysis of geothermal district heating 
systems: an application. Build Environ 2005;40:1309-22. doi:10.1016/j.buildenv.2004.11.001.

[14] Lund H, Werner S, Wiltshire R, Svendsen S, Thorsen JE, Hvelplund F, et al. 4th Generation District Heating (4GDH). Energy 2014;68:1-11. doi:10.1016/j.energy.2014.02.089.

[15] International District Energy Association. District Energy Space 2014. 2014.

[16] Jiang XS, Jing ZX, Li YZ, Wu QH, Tang WH. Modelling and operation optimization of an integrated energy based direct district water-heating system. Energy 2014;64:375-88. doi:10.1016/j.energy.2013.10.067.

[17] Jie P, Tian Z, Yuan S, Zhu N. Modeling the dynamic characteristics of a district heating network. Energy 2012;39:126-34. doi:10.1016/j.energy.2012.01.055.

[18] Kaliatka A, Valinčius M. Modeling of pipe break accident in a district heating system using RELAP5 computer code. Energy 2012;44:813-9. doi:10.1016/j.energy.2012.05.011.

[19] Bonilla JJ, Blanco JM, López L, Sala JM. Technological recovery potential of waste heat in the industry of the Basque Country. Appl Therm Eng 1997;17:283-8. doi:10.1016/S13594311(96)00024-5.

[20] Chinese D, Meneghetti A, Nardin G. Waste-to-energy based greenhouse heating: exploring viability conditions through optimisation models. Renew Energy 2005;30:1573-86. doi:10.1016/j.renene.2004.11.008.

[21] Lunghi P. Energy recovery from industrial waste of a confectionery plant by means of BIGFC plant. Energy 2004;29:2601-17. doi:10.1016/j.energy.2004.05.016.

[22] Connolly D, Lund H, Mathiesen BV, Werner S, Möller B, Persson U, et al. Heat Roadmap Europe: Combining district heating with heat savings to decarbonise the EU energy system. Energy Policy 2014;65:475-89. doi:10.1016/j.enpol.2013.10.035.

[23] Wiltshire R. Low temperature district energy systems. Proc. 16th Build. Serv., 2011, p. 91-9.

[24] Connolly D, Mathiesen BV, Østergaard PA, Møller B, Nielsen S, Lund H, et al. Heat Roadmap Europe 2050: First pre-study for EU27. 2012.

[25] Lund H, Möller B, Mathiesen BV, Dyrelund A. The role of district heating in future renewable energy systems. Energy 2010;35:1381-90. doi:10.1016/j.energy.2009.11.023.

[26] Fabrizio E, Seguro F, Filippi M. Integrated HVAC and DHW production systems for Zero Energy Buildings. Renew Sustain Energy Rev 2014;40:515-41. doi:10.1016/j.rser.2014.07.193.

[27] Danielewicz J, Śniechowska B, Sayegh MA, Fidorów N, Jouhara H. Three-dimensional numerical model of heat losses from district heating network pre-insulated pipes buried in the ground. Energy 2015. doi:10.1016/j.energy.2015.07.012.

[28] Andrews D, Pardo-garcia N, Krook-Riekkola A, Tzimas E, Serpa J, Carlsson J, et al. Background Report on EU-27 District Heating and Cooling Potentials , Barriers , Best Practice and Measures of Promotion Contact information. 2012. doi:10.2790/47209.

[29] Rosen MA, Le MN, Dincer I. Efficiency analysis of a cogeneration and district energy system. Appl Therm Eng 2005;25:147-59. doi:10.1016/j.applthermaleng.2004.05.008.

[30] Mancarella P. MES (multi-energy systems): An overview of concepts and evaluation models. Energy 2014;65:1-17. doi:10.1016/j.energy.2013.10.041.

[31] Powell KM, Sriprasad A, Cole WJ, Edgar TF. Heating, cooling, and electrical load forecasting for a large-scale district energy system. Energy 2014;74:877-85. doi:10.1016/j.energy.2014.07.064.

[32] Manfren M, Caputo P, Costa G. Paradigm shift in urban energy systems through distributed generation: Methods and models. Appl Energy 2011;88:1032-48. doi:10.1016/j.apenergy.2010.10.018.

[33] Chicco G, Mancarella P. Distributed multi-generation: A comprehensive view. Renew Sustain Energy Rev 2009;13:535-51. doi:10.1016/j.rser.2007.11.014.

[34] Karger CR, Hennings W. Sustainability evaluation of decentralized electricity generation. Renew Sustain Energy Rev 2009;13:583-93. doi:10.1016/j.rser.2007.11.003.

[35] Fabrizio E, Corrado V, Filippi M. A model to design and optimize multi-energy systems in buildings at the design concept stage. Renew Energy 2010;35:644-55. doi:10.1016/j.renene.2009.08.012.

[36] Agrell PJ, Bogetoft P. Economic and environmental efficiency of district heating plants. Energy 
Policy 2005;33:1351-62. doi:10.1016/j.enpol.2003.12.011.

[37] Frangopoulos CA. A method to determine the power to heat ratio, the cogenerated electricity and the primary energy savings of cogeneration systems after the European Directive. Energy 2012;45:52-61. doi:10.1016/j.energy.2011.12.044.

[38] Ó Broin E, Mata É, Göransson A, Johnsson F. The effect of improved efficiency on energy savings in EU-27 buildings. Energy 2013;57:134-48. doi:10.1016/j.energy.2013.01.016.

[39] Fragaki A, Andersen AN, Toke D. Exploration of economical sizing of gas engine and thermal store for combined heat and power plants in the UK. Energy 2008;33:1659-70. doi:10.1016/j.energy.2008.05.011.

[40] Lund H. Electric grid stability and the design of sustainable energy systems. Int J Sustain Energy 2005;24:45-54. doi:10.1080/14786450512331325910.

[41] Torchio MF, Genon G, Poggio A, Poggio M. Merging of energy and environmental analyses for district heating systems. Energy 2009;34:220-7. doi:10.1016/j.energy.2008.01.012.

[42] Brkić D, Tanasković TI. Systematic approach to natural gas usage for domestic heating in urban areas. Energy 2008;33:1738-53. doi:10.1016/j.energy.2008.08.009.

[43] Hein KR., Bemtgen J. EU clean coal technology - co-combustion of coal and biomass. Fuel Process Technol 1998;54:159-69. doi:10.1016/S0378-3820(97)00067-2.

[44] Lowe R. Combined heat and power considered as a virtual steam cycle heat pump. Energy Policy 2011;39:5528-34. doi:10.1016/j.enpol.2011.05.007.

[45] Danish Energy Authority, Energinet.dk. Technology Data for Energy Plants. vol. 978-87-784. 2012. doi:ISBN: 978-87-7844-857-6.

[46] US Environmental Protection Agency. Catalog of CHP Technologies. 2015.

[47] Krewitt W, Nitsch J, Fischedick M, Pehnt M, Temming H. Market perspectives of stationary fuel cells in a sustainable energy supply system-long-term scenarios for Germany. Energy Policy 2006;34:793-803. doi:10.1016/j.enpol.2004.08.010.

[48] Singhal S. Advances in solid oxide fuel cell technology. Solid State Ionics 2000;135:305-13. doi:10.1016/S0167-2738(00)00452-5.

[49] Lisbona P, Corradetti A, Bove R, Lunghi P. Analysis of a solid oxide fuel cell system for combined heat and power applications under non-nominal conditions. Electrochim Acta 2007;53:1920-30. doi:10.1016/j.electacta.2007.08.046.

[50] Yu Z, Han J, Cao X, Chen W, Zhang B. Analysis of total energy system based on solid oxide fuel cell for combined cooling and power applications. Int J Hydrogen Energy 2010;35:2703-7. doi:10.1016/j.ijhydene.2009.04.043.

[51] Ajah A, Mesbah A, Grievink J, Herder P, Falcao P, Wennekes S. On the robustness, effectiveness and reliability of chemical and mechanical heat pumps for low-temperature heat source district heating: A comparative simulation-based analysis and evaluation. Energy 2008;33:908-29. doi:10.1016/j.energy.2007.12.003.

[52] KLEMES J, FRIEDLER F. PRES 2006-Energy resources and management: Heat integration, heat pumps, emissions and waste to energy. Energy 2008;33:837-41. doi:10.1016/j.energy.2008.02.016.

[53] Keppo I, Savola T. Economic appraisal of small biofuel fired CHP plants. Energy Convers Manag 2007;48:1212-21. doi:10.1016/j.enconman.2006.10.010.

[54] Eriksson O, Finnveden G, Ekvall T, Björklund A. Life cycle assessment of fuels for district heating: A comparison of waste incineration, biomass- and natural gas combustion. Energy Policy 2007;35:1346-62. doi:10.1016/j.enpol.2006.04.005.

[55] Brand M, Svendsen S. Renewable-based low-temperature district heating for existing buildings in various stages of refurbishment. Energy 2013;62:311-9. doi:10.1016/j.energy.2013.09.027.

[56] Nádor A, Orosz L, Simó B, Hofmeister M. Promote Geothermal District Heating Systems in Europe Geothermal DH potential in Europe 2014.

[57] European Parliament. Directive 2012/27/EU of the European Parliament and of the Council of 25 October 2012 on energy efficiency. Off J Eur Union Dir 2012:1-56. doi:10.3000/19770677.L_2012.315.eng.

[58] Euroheat \& Power. District Heating \& Cooling: A vision towards 2020-2030-2050. 2011. 
[59] Li P, Nord N, Ertesvåg IS, Ge Z, Yang Z, Yang Y. Integrated multiscale simulation of combined heat and power based district heating system. Energy Convers Manag 2015;106:33754. doi:10.1016/j.enconman.2015.08.077.

[60] Dumas P, Stakeholder E, Cities S. Geothermal integration in Smart cities : Key Innovation in Smart Thermal Grids Smart cities \& communities. 2013.

[61] Nielsen S. A geographic method for high resolution spatial heat planning. Energy 2014;67:35162. doi:10.1016/j.energy.2013.12.011.

[62] European Parliament. Directive 2010/31/EU of the European Parliament and of the Council of 19 May 2010 on the energy performance of buildings (recast). 2010.

doi:doi:10.3000/17252555.L_2010.153.eng.

[63] Economidou M, Laustsen J, Ruyssevelt P, Staniaszek D, Strong D, Zinetti S. Europe' s buildings under the microscope: A country-by-country review of the energy performance of buildings. 2011.

[64] Intelligent energy Europe Programme. Energy Efficiency Trends and Policies in the EU An Analysis Based on the ODYSSEE and MURE Databases. 2015.

[65] Euroheat \& Power Statistics n.d. http://euroheat.org.

[66] Simoneit BR. Biomass burning - a review of organic tracers for smoke from incomplete combustion. Appl Geochemistry 2002;17:129-62. doi:10.1016/S0883-2927(01)00061-0.

[67] Lewtas J. Air pollution combustion emissions: characterization of causative agents and mechanisms associated with cancer, reproductive, and cardiovascular effects. Mutat Res 2007;636:95-133. doi:10.1016/j.mrrev.2007.08.003.

[68] Cohen AJ. Outdoor air pollution and lung cancer. Environ Health Perspect 2000;108 Suppl:743-50.

[69] Risom L, Møller P, Loft S. Oxidative stress-induced DNA damage by particulate air pollution. Mutat Res 2005;592:119-37. doi:10.1016/j.mrfmmm.2005.06.012.

[70] Brunekreef B, Holgate ST. Air pollution and health. Lancet 2002;360:1233-42. doi:10.1016/S0140-6736(02)11274-8.

[71] Allegrini J, Orehounig K, Mavromatidis G, Ruesch F, Dorer V, Evins R. A review of modelling approaches and tools for the simulation of district-scale energy systems. Renew Sustain Energy Rev 2015;52:1391-404. doi:10.1016/j.rser.2015.07.123.

[71] Chow T., Au W., Yau R, Cheng V, Chan A, Fong K. Applying district-cooling technology in Hong Kong. Appl Energy 2004;79:275-89. doi:10.1016/j.apenergy.2004.01.002.

[73] Dodoo A, Gustavsson L, Sathre R. Building energy-efficiency standards in a life cycle primary energy perspective. Energy Build 2011;43:1589-97. doi:10.1016/j.enbuild.2011.03.002.

[74] Dondi P, Bayoumi D, Haederli C, Julian D, Suter M. Network integration of distributed power generation. J Power Sources 2002;106:1-9. doi:10.1016/S0378-7753(01)01031-X.

[75] Eriksson M, Vamling L. Future use of heat pumps in Swedish district heating systems: Shortand long-term impact of policy instruments and planned investments. Appl Energy 2007;84:1240-57. doi:10.1016/j.apenergy.2007.02.009.

[76] European Commission. Energy 2020 - A strategy for competitive, sustainable and secure energy. Commun FROM Comm TO Eur Parliam Counc Eur Econ Soc Comm Comm Reg 2015;1:1689-99. doi:10.1017/CBO9781107415324.004.

[77] European Environment Agency. Air quality in Europe - 2012 report. 2012. doi:10.22775.

[78] Fang H, Xia J, Jiang Y. Key issues and solutions in a district heating system using low-grade industrial waste heat. Energy 2015;86:589-602. doi:10.1016/j.energy.2015.04.052.

[79] Gebremedhin A. Optimal utilisation of heat demand in district heating system-A case study. Renew Sustain Energy Rev 2014;30:230-6. doi:10.1016/j.rser.2013.10.009.

[80] Goulding J. European Directory of Sustainable and Energy Efficient Building 1999: Components, Services, Materials. Routledge; 1999.

[81] International Energy Agency. CO2 Emissions from Fuel Combustion 2014. IEA; 2014. doi:10.1787/co2_fuel-2014-en.

[82] Karlsson M, Gebremedhin A, Klugman S, Henning D, Moshfegh B. Regional energy system optimization - Potential for a regional heat market. Appl Energy 2009;86:441-51. 
doi:10.1016/j.apenergy.2008.09.012.

[83] Kelly S, Pollitt M. An assessment of the present and future opportunities for combined heat and power with district heating (CHP-DH) in the United Kingdom. Energy Policy 2010;38:693645. doi:10.1016/j.enpol.2010.07.010.

[84] Li H, Sun Q, Zhang Q, Wallin F. A review of the pricing mechanisms for district heating systems. Renew Sustain Energy Rev 2015;42:56-65. doi:10.1016/j.rser.2014.10.003.

[85] Li Y, Fu L, Zhang S. Technology application of district heating system with Co-generation based on absorption heat exchange. Energy 2015;90:663-70. doi:10.1016/j.energy.2015.07.090.

[86] Liu M, Shi Y, Fang F. Combined cooling, heating and power systems: A survey. Renew Sustain Energy Rev 2014;35:1-22. doi:10.1016/j.rser.2014.03.054.

[87] Lund H, Šiupšinskas G, Martinaitis V. Implementation strategy for small CHP-plants in a competitive market: the case of Lithuania. Appl Energy 2005;82:214-27. doi:10.1016/j.apenergy.2004.10.013.

[88] Lund H. Flexible energy systems: integration of electricity production from CHP and fluctuating renewable energy. Int J Energy Technol Policy 2003;1:250. doi:10.1504/IJETP.2003.002376.

[89] Lund H, Andersen AN, Østergaard PA, Mathiesen BV, Connolly D. From electricity smart grids to smart energy systems - A market operation based approach and understanding. Energy 2012;42:96-102. doi:10.1016/j.energy.2012.04.003.

[90] Lund JW. Geothermal energy focus. Refocus 2006;7:48-51. doi:10.1016/S14710846(06)70660-6.

[91] Nuytten T, Claessens B, Paredis K, Van Bael J, Six D. Flexibility of a combined heat and power system with thermal energy storage for district heating. Appl Energy 2013;104:583-91. doi:10.1016/j.apenergy.2012.11.029.

[92] Pirouti M, Bagdanavicius A, Ekanayake J, Wu J, Jenkins N. Energy consumption and economic analyses of a district heating network. Energy 2013;57:149-59. doi:10.1016/j.energy.2013.01.065.

[93] Shamshirband S, Petković D, Enayatifar R, Hanan Abdullah A, Marković D, Lee M, et al. Heat load prediction in district heating systems with adaptive neuro-fuzzy method. Renew Sustain Energy Rev 2015;48:760-7. doi:10.1016/j.rser.2015.04.020.

[94] Werner S. Encyclopedia of Energy. Elsevier; 2004. doi:10.1016/B0-12-176480-X/00214-X.

[95] Wood J. Local Energy: Distributed generation of heat and power. The Institution of Engineering and Technology; 2008.

[96] Bordin C, Gordini A, Vigo D. An optimization approach for district heating strategic network design. Eur J Oper Res 2016. doi:10.1016/j.ejor.2015.12.049.

[97] Cooper SJG, Hammond GP, Norman JB. Potential for use of heat rejected from industry in district heating networks, GB perspective. J Energy Inst 2016;89:57-69. doi:10.1016/j.joei.2015.01.010.

[98] Fazeli R, Davidsdottir B, Hallgrimsson JH. Residential energy demand for space heating in the Nordic countries: Accounting for interfuel substitution. Renew Sustain Energy Rev 2016;57:1210-26. doi:10.1016/j.rser.2015.12.184.

[99] Ghafghazi S, Sowlati T, Sokhansanj S, Bi X, Melin S. Particulate matter emissions from combustion of wood in district heating applications. Renew Sustain Energy Rev 2011;15:301928. doi:10.1016/j.rser.2011.04.001.

[100] Gustafsson J, Sandin F. Advanced District Heating and Cooling (DHC) Systems. Elsevier; 2016. doi:10.1016/B978-1-78242-374-4.00012-4.

[101] Nuorkivi A. Advanced District Heating and Cooling (DHC) Systems. Elsevier; 2016. doi:10.1016/B978-1-78242-374-4.00002-1.

[102] Ozgener L, Hepbasli A, Dincer I. A key review on performance improvement aspects of geothermal district heating systems and applications. Renew Sustain Energy Rev 2007;11:1675-97. doi:10.1016/j.rser.2006.03.006.

[103] Pauschinger T. Advanced District Heating and Cooling (DHC) Systems. Elsevier; 2016. doi:10.1016/B978-1-78242-374-4.00005-7. 
[104] Pol O, Schmidt R-R. Advanced District Heating and Cooling (DHC) Systems. Elsevier; 2016. doi:10.1016/B978-1-78242-374-4.00015-X.

[105] Wang P, Sipilä K. Energy-consumption and economic analysis of group and building substation systems - A case study of the reformation of the district heating system in China. Renew Energy 2016;87:1139-47. doi:10.1016/j.renene.2015.08.070.

[106] Ziemele J, Pakere I, Blumberga D. The future competitiveness of the non-Emissions Trading Scheme district heating systems in the Baltic States. Appl Energy 2016;162:1579-85. doi:10.1016/j.apenergy.2015.05.043.

[107] Babiarz B, Chudy-Laskowska K. Forecasting of failures in district heating systems. Eng Fail Anal 2015;56:384-95. doi:10.1016/j.engfailanal.2014.12.017.

[108] Himpe E, Janssens A, Rebollar JEV. Energy and Comfort Performance Assessment of Monitored Low Energy Buildings Connected to Low-temperature District Heating. Energy Procedia 2015;78:3465-70. doi:10.1016/j.egypro.2015.12.331.

[109] Sakawa M. Advanced District Heating and Cooling (DHC) Systems. Elsevier; 2016. doi:10.1016/B978-1-78242-374-4.00013-6.

[110] Ancona MA, Branchini L, De Pascale A, Melino F. Smart District Heating: Distributed Generation Systems' Effects on the Network. Energy Procedia 2015;75:1208-13. doi:10.1016/j.egypro.2015.07.157.

[111] Ivner J, Broberg Viklund S. Effect of the use of industrial excess heat in district heating on greenhouse gas emissions: A systems perspective. Resour Conserv Recycl 2015;100:81-7. doi:10.1016/j.resconrec.2015.04.010.

[112] Li H, Wang SJ. Load Management in District Heating Operation. Energy Procedia 2015;75:1202-7. doi:10.1016/j.egypro.2015.07.155.

[113] Soltani R, Dincer I, Rosen MA. Thermodynamic analysis and performance assessment of an integrated heat pump system for district heating applications. Appl Therm Eng 2015;89:833-42. doi:10.1016/j.applthermaleng.2015.06.048. 